\title{
Citizenship and the Social Position of Athenian Women in the Classical Age. A Prospect for Overcoming the Antithesis of Male and Female
}

\author{
By Jayoung Che*
}

Opinions range from one extreme to the other on the position of women in Classical Athens. The orthodox view, coming down from the late 19th century and the early 20th century, is that Greek citizen wives were generally despised and kept in seclusion. From the first half of the 20th century, however, challenges have been raised against the alleged subjugation of women, with the contention that women were respected and enjoyed more freedom than was thought. In the last half of the 20 th century S.B. Pomeroy gave a warning that women should not be treated as an undifferentiated mass, and contended that different standards should be applied to the categories of citizens, resident foreigners (metoikoi), and slaves.In my opinion, however, the differences among social groups should not refer just to women, but to the citizens themselves. The criterion for citizenship is not one and the same for all the epochs and places. Furthermore, in the same society there could be multiple criteria for citizenship. For example, one is the political rights to assume military service and magistrates of the government and to vote in the assembly, and the other is some traditional rights inside the family and its related kinship, demos and phyle, which were sub-structures of polis. The women, who did not participate in the government, were also called citizens (aste or politis), as they had social and economic rights in the family and kinship society. Actually, as considerable parts of the functions of polis were carried out on the level of its sub-structures, the politics of polis in ancient Greek society assume less significance than they do in the modern state today.

\section{Introduction}

Misunderstanding has been widely spread regarding the relationship among men, women and slaves. It used to be said that the ancient Greek polis was composed of male-citizens, and women did not have any franchise so that they were similar to slaves. However, in contemporary texts women were called also citizens like men. ${ }^{1}$ It is proved in the nomenclature of men and women: astos/aste and polites/politis. ${ }^{2}$

* Associate Professor, Busan University of Foreign Studies, Republic of Korea.

1. These days, Western scholars nearly do not deny that women were citizens just as men were. The discussion, however, refers to whether their social status was inferior or equal to that of men. Cf. S.B. Pomeroy, Goddesses, Whores, Wives and Slaves: Women in classical Antiquity (London, 1975), 58; D.C. Richter, "The Position of Women in Classical Athens," Classical Journal, LXVII(1971): 1.

2. For the laws which prove women were citizens, cf. Carystios, Fr. 11(FHG, IV, 358 $=$ Athenaios, XIII, 577b) In the archon year of Eukleides, Aristophon propsed the law that those born of non-citizen women be bastards (nothos), which was the renewal of the famous law of Perikles; cf. Scholia, Aischines, I, 39; Dem. LVII, 29ff.: LVII, 46: LIX, 122; Isaios, VIII, 43f.; Aristoteles, Athenaion Politeia, XLII, 1. 
Why did it come to be a kind of common sense notion that citizenship was appropriated only to men, and not women? In all likelihood, it is due to the fact that only men could take part in the assembly to vote and they, not women, served in the military forces. In my opinion, however, this misconception impedes accurate comprehension not only of citizenship but comprehensively of the whole ancient Athenian society. Also the concept of citizenship has to be differentiated from that of franchise. If the latter is related to the activity of voting and serving in the military, i.e. taking part in the political affairs (metechein politeias), the former is more comprehensive referring to every kind of initiative including economic and social rights.

Generally, in ancient society the proportion of political activity in everyday life was less than in the modern. Various categories of social group, family, clan (gene), tribe (phyle), kome (village), or other religious or vocational groups, had more gravity rather, or no less, than, those related to political affairs. Ancient society was a multi-centric one, and the influence of the kinship society was relatively stronger than that of the modern age. When we talk about the women who had a citizenship, it means that they enjoyed social or economic rights or privileges which were not political.

Since the beginning of the $20^{\text {th }}$ century, controversy has appeared regarding the social status of Athenian women. There have been extremely polarized opinions presented: the Athenian women were isolated in the house under the pressure of the men commanding an andro-centric society on the one hand, ${ }^{3}$ and they were considerably free to take initiatives at home as well as in the arena of non-domestic social activities on the other. ${ }^{4}$ There was also an intermediate position to reconcile the two extremities. ${ }^{5}$ For example, Lacey accepted that the Athenian women's activities were restricted within the house, being isolated from society, but suggested it was due to the mechanism protecting them rather than the oppression of men.

However, the conception of the so called "women" as a whole is quite ambiguous. Pomeroy argued that there is a fundamental deficiency on the discussion of women's social position, since women are discussed as a whole. And she categorized them according to social or economic status into citizens, metoikoi (resident foreigner), and slaves. These categories, as Pomeroy says, are applied not only to men but women, so that the longpending dispute on the status of women could not result in a successive

3. F.A. Wright, Feminism in Greek Literature: from Homer to Aristotle (N.Y.: 1969), 1. For the bibliography of similar discussions at the beginning of the 20th century, cf. A.W. Gomme, "The Position of Women in Athens in the Fifth and Fourth Centuries B.C.," in Essays in Greek History and Literature (Oxford, 1937), 89.

4. Ibid., 89-115; M. Hadas, "Observations on Athenian Women," CW 39 (1936), $97-$ 100; H. D. F. Kitto, The Greeks (Harmondsworth, 1951), .219- 36; Ch. Seltmann, Women in Antiquity (London, 1956), 110-11; Ch. Seltmann, "The Status of Women in Athens," Greece and Rome, 2nd ser., II(1955): 119-124. Cf. D.C. Richter, "The Position of Women in Classical Athens," 1-8.

5. V. Ehrenberg, The people of Aristophanes: A Sociology of Old Attic Comedy (New York, 1962), ch. 8; W. K. Lacey, The Family in Classical Greece (Ithaca, New York: Cornell University Press, 1968), ch.7. 
conclusion, because the question is based on the faulty premise which concerns just the relative position of women to men.

This essay is to review Athenian women's social status on two points of dispute. First, like men, women could be divided into different categories: citizens and non-citizens. Further, the qualification of citizenship could change according to epoch and region. Moreover, even among citizenship types there could be differences, complete or incomplete. On the other hand, sometimes there were no clear distinctions between citizens and noncitizens. In this case, the distinction itself among citizens, non-citizens and slaves does not have any significance. In case of need, citizenship was ever granted to resident foreigners. Thus, standardized and stagnant dualism which divides citizens and non-citizens as well as men and women should be refused.

The second point is how to properly understand the literary sources, whose contents seem contradictory concerning women's social status. In my opinion, a clue could be found to solve the problem if we suppose that the sources which disparage women do not reflect the reality itself, but expectations which have not been fully realized. And the confrontation which seems superficially to be between men and women does not refer to the division of biological sex or gender, but eventually to the difference of orientation in social mechanism between moderation and indulgence, or between peace and war.

\section{Citizenship and the Role of Substructures of Polis}

Although feminine was definitely described as a citizen, "aste" or "politis", in classical Athens, these terms are sometimes taken as empty titles. Furthermore, a dominant traditional view takes citizenship as a bundle of political rights and denies that women were part of the "citizen's club"; or if the notion of "female citizenship" is implied, at times unavoidably, as in reference to the citizenship law requiring birth from "two citizen parents", this is explicitly understood to be mere place-holding or reflection of male relatives' authentic citizen status. ${ }^{6}$

On the other hand, there are other arguments referring to contradictory evidence regarding women's capacities where economic transactions were concerned. Although an Athenian law prescribes that women could not conduct a transaction worth more than a certain amount of barley (a medomnos), ${ }^{7}$ there are actual instances of transactions of significant value conducted by women.

6. Cf. J.K. Davies, "Athenian Citizenship: The Descent Group and Alternatives," Classical Journal 73(1977): 105-121; R. Sealey, A History of the Greek City States, ca. 700-338 B.C. (Berkeley: University of California Press, 1976), 14. For a critical comments to these opinions, cf. C. Patterson, "The case against Neaira and the Public Ideology of the Athenian family," in Athenian Identity and Civic Ideology, ed. A.L. Boegehold and A.C. Scafuro (Baltimore: John Hopkins University Press 1994), $201 \mathrm{f}$.

7. Cf. Isaios, 10.10; Aristophanes, Ecc. 1024-25. S. Johnstone, "Women, property, and surveillance in classical Athens," Classical Antiquity 22-2(2003), 247, argues that a "medimnnos" 
Johnstone accepted the dominant view that Athenian women suffered an inferior social status and were legally subject to men. Concerning women's capacities for economic transaction, however, he tried to harmonize two contradictory pieces of evidence. He denied the views of the scholars who, attempting to understand women as more than just passive victims of men's subjugation, represented Athenian women as autonomous, capable agents, and treated the control of property as a kind of freedom. ${ }^{8}$ Instead, he insisted that, although the women were legally unable to pursue their own interests, many Athenian women might have exercised informal control over property through personal trust by an affectionate relationship with their "kyrioi" (masters).

His argument is that there were two different kinds of social relationships through which the control of property was guaranteed: publically through citizens or privately through friends. It refers to the distinction between visible (phanera onta) and invisible (aphanes ousia) property, ${ }^{9}$ the entailed distinction between impersonal and personal trust, and the possibilities of disaggregating or aggregating instrumental and affectionate relationships. ${ }^{10}$ To hold visible property was to subject oneself to impersonal and formal relationships surveillance with two audiences, witnesses and jurors. To hold invisible property was to depend on personal relationships of trust. ${ }^{11}$ Generally, the former item in each of these contrasts refers to male citizens, and the latter to women.

A man who held visible property put himself under the surveillance of two kinds of audiences: witnesses and jurors. Johnstone called these audiences "formal" because they shared three characteristics: 1 . indiscriminate among those eligible, interchangeable, and functionally equal; 2 . reciprocal but asymmetrical; 3 . depersonalization of the relationships, ${ }^{12}$ and he insists that, as a man could rely on his relationships with his fellow citizens to guarantee his ownership of property, he did not need to use his friends to do this. ${ }^{13}$ In contrast, however, Athenian women may have exercised informal control over property, by intensifying their relationships with their "kyrios". Just as the owner of invisible property had to cultivate a relationship of trust with the holder of his property, so an Athenian woman, too, needed to maintain a good relationship with her "kyrios". ${ }^{14}$

Patterson, however, challenged these theories, declaring that she was in no way advocating a return to the long influential patriarchal and patrilineal

was a modest but not trivial quantity, which would have been enough barley to feed a family of five for 5 or 6 days. .

8. S. Johnstone, "Women, property, and surveillance in classical Athens", 247-274. Cf. R. Brock, "The labour of Women in Classical Athens," Classical Quarterly 44-2(1994): 336ff.

9. According to Johnstone ("Women, property, and surveillance," 248), visible and invisible property did not name different kinds of property (e.g., land versus cash), but whether the owner publically acknowledged the property as his. Any property (even land) could be invisible if the owner took steps to conceal not the thing itself but his ownership of it.

10. Ibid., 267.

11. Ibid., 248.

12. Ibid., $250 \mathrm{f}$.

13. Ibid., 258.

14. Ibid., 247f. $267 \mathrm{ff}$. 
paradigm of ancient society put forth by Fustel de Coulanges in $1864 .{ }^{15}$ Above all, she pointed out that it is erroneous to assume that the public/ private distinction in classical Athens neatly corresponds to male/female spheres of responsibility. ${ }^{16}$ And Athenian women were themselves in some ways "exploiters" of the non-Athenian and the non-free. According to Patterson, Athenian women should be seen as standing within the citizen class as participants in the polis in ways marking them off in law and in public consciousness from the non-Athenian and the non-free - as we could say, share-holders rather than place-holders. ${ }^{17}$ As an example, she adduces "Against Neaira", an oration of Demosthenes. ${ }^{18}$

In the "Against Neaira", two plaintiffs, Apollodoros and his brother in law, Theomnestos, condemned Neaira for feigning herself to be of citizen status, living together as the wife of an Athenian citizen, Stephanos. Neaira who, at age fifty-five or thereabouts, is on trial for usurpation of citizenship (graphe xenias), while the attack on Neaira is simply a way of getting at her man. In order to ruin Stephanos, with whom Neaira is apparently living, Apollodoros attacks the character and status of his "wife". Apollodoros would not have been interested in Neaira if she were not living with Stephanos. If Neaira is convicted, Stephanos stands to be fined one thousand drachmai, but as head of an oikos, he potentially loses much more (Dem. 59.16). If Neaira is convicted of acting as his wife, then the legitimacy of the entire oikos is called into question, the citizen status of his children being exposed to a high vulnerability. ${ }^{19}$

Furthermore, according to the plaintiff, Neaira and Stephanos have married Phano, Neaira's daughter by an unknown father, twice to Athenian citizens as though she were Stephanos' own daughter. This alleged action contradicts the law which says, "If anyone shall give an alien woman in marriage to an Athenian man representing her as being related to himself, he shall lose his civil rights and his property shall be confiscated ..." (Dem. 59.52). ${ }^{20}$ The plaintiff also accused Stephanos of introducing children who actually were not his own but were presented as his own to his fellowclansmen (phraterai) and demesmen (demotai); that he had given in marriage the daughters of a courtesan as though they were his own; that he is guilty of impiety towards the gods; and that he nullifies the right of the people to bestow its own favors, if it chooses to admit anyone to citizenship (Dem. 59.13). ${ }^{21}$

15. Ibid., 200.

16. C. Patterson, "The case against Neaira and the Public Ideology of the Athenian family," 201.

17. Ibid., 202.

18. Ibid., p.199ff.

19. A.H.R. Harrison, The Law of Athens, I Family and Property (Oxford: Clarendon Press, 1968), 142-149; Lin Foxhall, "Household, Gender and Property in Classical Athens," Classical Quarterly 39(1989): 22-44; C. Patterson, "The case against Neaira and the Public Ideology of the Athenian family," 202f, 212.

20. Cf. C. Patterson, "The case against Neaira and the Public Ideology of the Athenian family," p.207f.

21. Cf. Ibid., 204. 
In connection with Phano, Patterson kept an eye on the fact that she was charged by Apollodoros on two grounds. First she has twice usurped the privilege of Athenian women as the wife of a Basileus and Phano has shamelessly presided over the most sacred and secret (hagia kai aporrheta) rites of Dionysos (Dem. 59.73: 75), even though the ancient law inscribed on a stele in the sanctuary of the god in Limnai required that the Basilina (Basileus' wife) be a "citizen woman (aste)" and a virgin-bride [i.e. a wife who has never had any relationship with another man except her husband (me epimemeigmene heteroi andri)] (Dem.59.76). Second, as an "adulteress" and woman of loose morals, Phano violated the law prohibiting such a woman from public sacrifices (Dem. 59.87). According to Patterson, ${ }^{22}$ irrelevant to the reality of Apollodoros' assertions related to Pano's identity, Phano's alleged sacrilege proves the emotional content and ideological implications of Apollodoros' narration. The polluted adulteress is excluded from the sacred public rituals (ta hiera ta demotele), and a female to suffer "atimia" (disqualification of citizenship cause of dishonor) is to be outcast (ekbeblemene) from the oikia of her husband and from the sacred rituals (ta hiera) of the city (Dem. 59.86). According to the law regarding adultery, "when he has caught the adulterer, it shall not be lawful for the one (i.e. male citizen) who has caught him to continue living with his wife, and if he does so, he shall lose his civil rights and it shall not be lawful for the woman who is taken in adultery to attend public sacrifices; and if she does attend them, she may be made to suffer any punishment whatsoever, short of death, and that with impunity" (Dem. 59.87). And in his final appeal Apollodoros calls upon the jury to imagine the rage of their female relatives if "you [have] deemed it right that this woman should share in like manner with themselves in the public ceremonials and religious rights (metechein ton tes poleos kai ton hieron) (Dem. 59.111)," and exhorts each juror to consider that he is voting in behalf of the female members of his oikos and for the polis, law and religion. ${ }^{23}$

Furthermore, with regard to the ground of qualified citizenship, the plaintiff raises the question, "who will any longer seek to win citizenship from you and to go undergo heavy expense and much trouble in order to become a citizen, when he can get what he wants from Stephanos at less expense, assuming that the result from him is to be the same?". Actually, one of two plaintiffs, Apollodoros, was himself the son of a former slave Pasion who was granted citizenship for himself as well as his descendants by the Athenian people (demos ton Athenaion) for his great contribution to them (Dem. 59.2).

It is ironic that the son of a former slave calls upon the Athenians to guard the citizenship and to throw Neaira back into slavery. According to Patterson, ${ }^{24}$ we see here the zealous patriotism of new citizens and the xenophobia of those who were only recently "xenoi" (aliens) themselves. As relevant for present purposes, however, it is shown that citizenship was

22. Ibid., 209.

23. Cf. Ibid., 210.

24. Ibid., 199 
granted at least on two bases; one qualified basically by the membership of oikos or its related kinship, and the second, in the case of aliens it could be granted by the decision of the "demos". In any case, marriage is a key element, Patterson, says, in the public ideology of Athens because it brings, through the oikos it creates, access to privilege and responsibilities in the public realm, and the rules of marriage and legitimacy illuminate the nature of both male and female participation in the Athenian polis. ${ }^{25}$ Thus, Patterson's understanding on the "Against Neaira" differs quite a bit from that of Johnstone, whose argument that Neaira had to maintain control of her property by her personal relationships with other patrons first or her "kyrios" later.

Going further beyond Patterson's opinion, however, our concern has to be turned toward the role of the substructures of polis, which intervenes between family with its related kin (oikos) and polis: phratria (brotherhood), demos, and tribe. Considerable parts of polis' functions operated not so much on the level of polis as on its substructures. And in the latter, social roles between male and female, as well as public and private, were not so clearly differentiated from each other. In this aspect, the political and social structures of polis were quite different from the modern state in which there is a relatively sharp distinction between public and private affairs. In my opinion, Johnstone's inflexible theory premised upon a clear distinction between male and female, as well as public and private lives, resulted from disregarding the very functions of various substructure levels of polis.

Above all, as discussed above, the citizenship that forms the basis of the polis originated from the acknowledgement of phratry and demos for the actual membership of oikos. It is evidenced in the Athenian Constitution (42.1), as following.

Citizenship belongs to persons of citizen parentage on both sides, and they are registered on the rolls of their demes at the age of eighteen. At the time of their registration the members of the deme make decisions about them by vote on oath, first whether they are shown to have reached the lawful age, and if they are held not to be of age they go back again to the boys, and secondly whether the candidate is a freeman and of legitimate birth; after this, if the vote as to free status goes against him, he appeals to the jury-court, and the demesmen (people of demos) elect five men from among themselves to plead against him, and if it is decided that he has no claim to be registered, the state sells him, but if he wins, it is compulsory for the demesmen to register him.

Thus, the citizenship of polis was not granted by the authority of polis, but firstly based on the membership of oikos, thence it should be acknowledged by "demos" or "phratry", which were substructures of polis. And male or female is not spoken of. As polis was fundamentally a

25. Ibid., 208f., 211. 
microcosmic world, and its citizenship was quite different from nationality in the contemporary world qualified by the authority of the state

In the case of Neaira, an alien in origin, she was reared as a slave and prostitute, but managed to win for herself both freedom and eventually settled into the domestic life of an Athenian citizen's household like an ordinary Athenian woman over a period of twenty years or so arriving eventually at her mid-fifties. If Apollodoros, who actually targeted at Stephanos, Neaira's husband, had not "blown the whistle", she would never have had any difficulties to get along as an Athenian woman herself as well as the legal wife of an Athenian citizen. ${ }^{26}$

Thus, a matter of course is that polis' political functions reduced relatively in comparison with that of the modern state, as the substructures of polis had initiatives in no small functions of polis, which were performed by the level of each demos or phratria (brotherhood). On the grounds of this very point, even if not assuming the responsibility as well as duty for voting or military service, females were qualified for citizenship and, it could be said, actively joined in public affairs.

Not only in acquisition of citizenship but in the role for every kind of rituals and the rights of inheritance, female was mostly equivalent to male. While mediated through the oikos, the women's share in the public good was seen in the care of and lament for the dead or the ritual celebration of fertility and marriage. According to Paterson, it was not only publically recognized but also legally enforced. ${ }^{27}$ Moreover, Patterson argues that both male and female Athenians were active shareholders in the property and fortunes of their oikoi (households) and polis. The Athenian woman through her oikos in public life and public ideology may very well contribute to a better understanding of the Athenian society and history. Athens was not a strictly patrilineal society in which property rights only descended through, or were restricted to, men; the matrilineal as well as patrilineal kin were included in the inheritance network (the anchisteia); and women themselves ought to be recognized as real heirs even if under the legal guardianship of a male relative. $^{28}$

Scholars used to treat woman's dowries as fundamentally different from other kinds of property as it gave the wife leverage over her husband. Johnstone, however, mentions that it is not necessary to treat dowry separately. ${ }^{29}$ This is why a wife does not legally own her dowry in the sense that she could not herself pursue her interests in it through litigation. Quoting Foxhall's argument, ${ }^{30}$ he underlines that women still need "kyrios". So, Johnstone concluded that with a dowry, as with property generally, a woman's attempts to control it depended ultimately upon using the relationship with a man close to her instrumentally. Johnstone set up an

26. Ibid., 207.

27. Ibid., 202.

28. A.H.R. Harrison, The Law of Athens, I Family and Property, 142-149; L. Foxhall, "Household, Gender and Property in Classical Athens," 22-44; C. Patterson, "The case against Neaira and the Public Ideology of the Athenian family," 202, 212.

29. S. Johnstone, "Women, property, and surveillance in classical Athens," 268f.

30. L. Foxhall, "Household, Gender and Property in Classical Athens," 39. 
antithesis between women and their "kyrioi". Johnstone says, (men) citizens participated in systems of collective action with other citizens, to cooperate without personal trust, knowledge, or affection, while women, excluded from this, had only one kind of relationships of personal trust with their "kyrioi".

Moreover, referring to the ability of litigation Johnstone supposed there is a difference between men holding visible property and women disposing of invisible property. ${ }^{31}$ According to him, to hold visible property was to constitute relationships with two kinds of audiences: citizens as witnesses and citizens as jurors. The first audience, witnesses, was restricted only to free adult males. Although free men who were not citizens "could" testify, Johnstone argues, the vast majority of witnesses in fact were citizens. ${ }^{32}$ The relationship of one citizen to others as witnesses must be analytically distinguished from relations with friends, neighbors, or kin. Even though they usually overlapped, being a witness was more generalized than being a friend, neighbor, or kinsman, since witnesses, unlike friends, were understood to be obliged to tell the truth. The second audience was citizens as jurors, with whom litigants constituted formally, though asymmetric, but reciprocal links between litigants and jurors by persuasion and voting. Therefore Johnstone concluded, holding visible property created dense networks of relationships between citizens. ${ }^{33}$

In my opinion, however, the discussion related to the male citizen ability for litigation has to be processed in a different context from the social relationship between men and women. Whether being qualified or not for litigation, cannot properly say anything about the relationship between men and women, as not only women but male minority and resident aliens also were not qualified.

With regard to this point, Aristotle says, as there are several forms of constitution, it follows that there are several kinds of citizens, and especially of citizens in a subject position. ${ }^{34}$ For example, there are those who have the right under a commercial treaty to sue and to be sued at law, or resident aliens who are obliged to produce a patron so that they only share in a common legal procedure to an incomplete degree. According to Aristotle, these are only citizens in the manner in which children who are as yet too young to have been enrolled in the list and old men who have been discharged must be pronounced to be citizens in a sense, yet not quite absolutely, but with the added qualification of "under age" in the case of the former and "superannuated" in the matter. ${ }^{35}$

Discussions regarding litigation also should be processed in a separate social context from citizenship or property ownership, as the latter has its roots deeply in kinship society while the former does not necessarily.

31. S. Johnstone, "Women, property, and surveillance in classical Athens," 252ff.

32. The ratio of witnesses between citizens and non-citizens is approximately 15 to 1 (141 citizens versus 9 non-citizens). For the list of the non-citizen witnesses, cf. A.R.W. Harrison, The Law of Athens: Procedure, v.2 (Oxford: Clarendon Press, 1971), 137, n.5.

33. S. Johnstone, "Women, property, and surveillance in classical Athens," 254f.

34. Aristoteles, Politika, 1278a 15-27.

35. Aristoteles, Politika, 1275a 11-23. 
Johnstone's theory related to the ability for litigation is as much arbitrary as the division between men holding visible property and women holding invisible property, which has no valid foundation from a logical point of view.

It has to be underlined that the restriction to the rights of economic transaction does not refer only to women but also to men. First of all, male minors were not qualified to perform economic transactions, so they were in an inferior status to adult females for whom it was permitted to deal with the limit of a medimnos. And adult men also, even if they were "kyrioi", could not dispose arbitrarily of every kind of property, as common ownership of kinship, especially in the case of land, was a widely spread convention in ancient societies, of which Athens surely did not make an exception. And a "kyrios" could neither dispose of commonly owned property nor, as well known, of his wife's dowry, as it is a peculiar property. In the event of divorce, the dowry has to be returned undamaged to the female's maiden home, and the fortunes produced by the efforts of the female must be attributed to her share. Even when the property was confiscated, dowry was exempt to be treated separately. ${ }^{36}$

Contrary to Jonestone's arguments it has to be underlined that dowry provides a vivid evidence for the existence of property which "kyrios" could not dispose of at ease. And beyond doubt there must have been other properties attributed to the common possessions of the members of a family (oikos), kin or tribe. Thus, it seems, not only women but also men themselves could not overcome a limitation imposed on a certain kind of property, and, if necessary, needed consent from the concerned relatives of his family or its related kin. Basically, it should not be forgotten that in ancient society generally a modern concept of exclusive possession did not fully develop, especially referring to land property. So, in order to understand properly the relationship between men and women, the intermediate social category of an extended family (oikos), phratria (brotherhood), demos, or tribe, which provided an indispensable basis of polis administration, should also be considered

From the discussion above, dualism between males and females in not applicable to the rights of economic transactions, as both were controlled more or less by the authority of kinship of extended family (oikos), phratry or demos. Different from Jonestone's argument, male economic transactions were performed under the surveillance of the same category of substructures of polis as those of female.

\section{Versatility of the Concept of Citizenship and Women}

Pomeroy argues that women did not consist of a group under the same conditions, so they should be treated differently from each other according to their social status: citizens, resident foreigners and slaves. In my opinion,

36. Cf. R. Garner, Law and Society in Classical Athens (N.Y.: St Martin's Press, 1987), 85. 
however, even among those of the same social status, the situation of women was not always the same. Moreover, sometimes the status itself changed according to the situation. Aristotle refers the changeability of citizenship as follows.

"... For in some democracies the son of a citizen-mother (politis) is a citizen (polites), and the same rule holds good as to base-born sons (gnesioi polites) in many places. Nevertheless, inasmuch as such persons are adopted as citizens owing to a lack of citizens of legitimate birth (for legislation of this kind is resorted to because of underpopulation), when a state becomes well off for numbers it gradually divests itself first of the sons of a slave (doulos) father or mother (doule), then of those whose mothers only were citizens, and finally only allows citizenship to the children of citizens on both sides." ${ }^{37}$

Aristotle also says, in an over-populous state foreigner and resident aliens will readily usurp the rights of citizens, for the excessive number of the population makes it not difficult to escape detection. ${ }^{38}$

In the case of Athens, generally opinions converged on the fact that, in the epoch of Solon when political authority was less developed than later, the distinction between citizen and non-citizen itself was not so apparent. Moreover, according to Plutarch, ${ }^{39}$ the law concerning naturalized citizens is of doubtful character. He (Solon) permitted only those to take part in political affairs (methexein tes politeias) who were permanently exiled from their own country, or who removed to Athens with their entire families to ply a trade. This he did, Plutarch says, not so much to drive away other foreigners, as to invite these particular ones to Athens with the full assurance of becoming citizens; he also thought that reliance could be placed both on those who had been forced to abandon their own country, and on those who had left it with a fixed purpose. And later, Aristotle informs, after the expulsion of the tyrants Cleisthenes enrolled in the tribe many resident aliens and slaves. And the dispute as to these is not about the fact of their citizenship (polites), but whether they received it wrongly or rightly. ${ }^{40}$

Solon's deal concerning citizenship is quite contrary to the enactment which was passed on the proposal of Pericles confining citizenship to persons of citizen birth (astoi) on both sides. According to the Athenian Constitution (Athenian Politeia) of Aristotle (XXVI.3), it was due to the large number of the citizens (politai) that an enactment was passed on the proposal of Pericles confining citizenship to persons of citizen birth on both sides.

On the other hand, at the end of the Peloponnesian War, in Athens the oligarchic regime established twice in 411/410 B.C. and again in 404/403

37. Aristoteles, Politika, 1278a 28-35.

38. Aristoteles, Politika, 1326b 20-23.

39. Plutarchos, Solon, XXI, 2.

40. Aristoteles, Politika, 1275b 35-38. 
B.C. In 411/410 B.C., the Athenians established first the regime of the Four Hundred, ${ }^{41}$ and soon after they dissolved it and handed over affairs to the Five Thousand that were on the armed roll. And in 404/403 B.C., three thousand citizens were enrolled, who were qualified to share in the government. ${ }^{42}$ According to Aristotle, who he is a citizen in a democracy will often not be a citizen in an oligarchy, as Aristotle's criterion for citizenship is in the strict sense that he shares in the administration of justice ("krisis") and in governance ("arche"). ${ }^{43}$

After the end of the Peloponnesian War, Thrasyboulos proposed the decree allowing citizenship all those who had come back together from Peiraeus, some of whom were clearly slaves, even if it was not actually realized. ${ }^{44}$ Anyway, during the archonship of Eucleides in 403 B.C., on the motion by Aristophon, an old law of Solon's (i.e. traditional law) was revived and put into effect, which declared that, in order to possess full civic rights, a man must be born of parents both of whom were Athenians. ${ }^{45}$

Then, it has to be remembered that Athenian women's ("Athenaia") citizenship does not refer directly to the rights to take part in government or political affairs, but to conventionally social or economic capacities. Both men and women, polites/politis and astos/aste do not necessarily refer to complete citizenship or franchise, but to the economic and social rights in various categories of social group, family, clan, etc. And these kinds of rights of women could be defined as incomplete - viewed on the criterion of political franchise. Aristotle, who regarded the true citizen as the man capable of governing, discussed incomplete citizenship as follows.

"... it is true that not all the persons indispensable for the existence of a state are to be deemed citizens, since even the sons of citizens are not citizens in the same sense as the adults: the latter are citizens in the full sense, the former are citizens only by presumption, but incomplete ones." 46

Athenian society was dualistic, which was proved already from the time of Cleisthenes: political organization on the one hand, and traditional clan (gene), brotherhood ("phratriai"), religious group (hyerosynai) on the other. The Athenian constitution (XXI. 2-6) refers to co-existence of both new and traditional after Cleisthenes' renovation of the political organization structure as follows.

"... [2] He first divided the whole body into ten tribes instead of the existing four ... [6] the clans and brotherhoods and priesthoods

41. Aristoteles, Athenaion Politeia, XXXIII.2.

42. Aristoteles, Athenaion Politeia, XXXVI.1.

43. Aristoteles, Politika, 1275a 2: 20-23.

44. Aristoteles, Athenaion Politeia, XL.2.

45. Cf. Dem. LVII, 30.

46. Aristoteles, Politika, 1277b 35-78a 6. 
belonging to the various demes he allowed to remain on the ancestral tradition."

Actually in the literary sources, "aste" (city woman) is more frequently used than "politis" (i.e. woman with a qualification related to the "polis"). Potentially the former is a more comprehensive concept including every kind of socio-economic qualification, not to speak of complete or incomplete citizenship

The citizen women or free women were not all in the same situation. According to a speaker of Demosthenes, even if his mother was a citizen ("politis"), suffering poverty she made service in the market selling ribbons and did not live in the manner, so that caused misunderstanding regarding her. ${ }^{47}$ And later Dion Chrisostomos said as follows.

"Lots of city women (astai gynaikes) did not have any support and were in a destitute situation, so that they gave birth to children of aliens as well as slaves. Sure, did they not do either intentionally or accidentally? No one of their children is to be slaves, but just not to be Athenian citizens." ${ }^{48}$

Categorizing the women into citizens, resident aliens and slaves, Pomeroy did not suppose each category, needless to say, including citizenwomen, was also composed of various groups of different social status.

\section{Harmonious Matching of Contradictory Sources Concerning Women's Status}

Contradictory arguments on the social status of women are due in large part to the literary sources which give us conflicting information regarding them. ${ }^{49}$ For example, it is now and then said that the virtue of women is to stay silent in the house or make a living with temperance (sophrosyne). ${ }^{50}$ And these comments are regarded as proving their inferior status to men. Actually, however, there is plenty of contrary evidence s which shows married women's free activities, sometimes attaining to arrogance and indulgence, ${ }^{51}$ attending at the sacrificial rites, ${ }^{52}$ athletic competition, ${ }^{53}$

47. Dem. LVII, 30-32.

48. Dion Chrysostomos, XV, 3.

49. For the opposite literary sources and views, cf. H.W. Haley, "The Social and Domestic Position of Women in Aristophanes," Harvard Studies in Classical Philology, Vol. 1(1890), 159-186; D.C. Richter, "The Position of Women in Classical Athens," 1-8.

50. Plutarchos, Moralia (Ethika), 217f: 220d; Aristoteles, Politika, 1260a 11-32; Euripides, Troades 645-656; Ibid., Herakleidai, 476 - for a woman silence is best, and modest behavior (sophronein), and staying quietly within doors; Aristophanes, F.253; Aristoteles, Politika, 1277b 22-25.

51. Cf. Alexandridas, F.52; Dowry makes the wife of a poor man be his master; Aristophanes, Lysistrata 409-410. Well, the other night in fervor of a dance her clasp broke open; Ibid. Thesmophoriazusai, 413-423 Formerly the old men married young girls, but they have been so calumniated that none think of them now, thanks to that line of his (cf. 
theatre ${ }^{54}$ trading in the market, ${ }^{55}$ divination, ${ }^{56}$ accompanying with neighbors, ${ }^{57}$ going out. ${ }^{58}$ According to Gomme, all the Athenian women are described as well informed of Euripides in the Thesmophoriazousai, proved as versed not only with politics in the Lysistrata, but current social affairs in the Thesmophoriazousai. ${ }^{59}$

Pomeroy mentioned that opinion differs according to which sources one selects. She says, Gomme depended mostly on the classic tragedies, as he regarded the female protagonists in them reflected the social circumstances of the $5^{\text {th }}$ century, and concluded that the women were not segregated but esteemed. To the contrary, Lacy, who asserted that women were actually in an inferior situation, argued that the persons described in the tragedies do not represent the common figures of normal houses. And according to Ehrenberg, only Euripides approaches the actual reality, but the women described in the works of Aischylos and Sophokles are rather unreal. According to Pomeroy, Lacy and Ehrenberg depended greatly on the Attic orators, while Gomme did hardly quote them. On the other hand, Hadas put forth the opinion that the legal orations are polemic as to be one-sided, but the comedies reflect moderately both sides.

Thus, Pomeroy commented that the discussions on women's social status are closely related to appraisals regarding the value of sources. ${ }^{60}$ Whoever regarded that Antigone and Electra in Aischylos and Sophocles represented the Athenian women in the $5^{\text {th }}$ century concluded that women's position was considerably esteemed, but those, depending on the orations and other literary sources of prose, appraised women to be in an inferior situation.

To the contrary, there is a suggestion that various aspects, sometimes even contradictory, of women show the periodical developments of actual women's social status. For example, already in the first half of the 20th century Botsford, argued that the works of Aischylos and the images described on the vases prove the importance of women's roles or their free

Aristophanes, Nephelai, 40-55); Platon, Politeia, 742-744 In order to restrict the wife's indulgence, her dowry should be reduced; Semonides, F.3 Phokylides: Mare with long hair is roaming about on the street.

52. Aristophanes, Acharneis, 241f.; Ibid. Lysistrata, 641f.; Aischines, I, 183; Theophrastos, XXVIII (The cult of Orpheus); the relief of the Parthenon.

53. Aristophanes, fr.471.

54. Ehrenberg, The people of Aristophanes, ch. 8 maintained that the women were prohibited to visit the theater. But there is an opposite view that they used to do so, cf. H.W. Haley, "The Social and Domestic Position of Women in Aristophanes," 1170ff.; Kitto, The Greeks, 233. Cf. Evidences in the literary sources, cf. Aristophanes, Thesmoporiazusai, 1228f. "Good and honest women returned directly from the theater to home"; Platon, Nomoi, 658d says, educated women preferred tragedy to comedy.

55. Cf Aristophanes, F.318; Ibid., Batrachoi, $1346 f$.

56. Theophrastos, Ch.17.

57. Euripides, Hippolytos, 125; Dem. LV, 23.0

58 Cf. Aristophanes, Thesmophoriazusai, 821f. (women's going out is inferred from "Parasol"); Batrachoi, 1346-1351.

59. A.W. Gomme, "The Position of Women in Athens," 102.

60. S.B. Pomeroy, Goddesses, Whores, Wives and Slaves, 59-60. 
status, but the texts in Pericles' memorial address ${ }^{61}$ and in Stobaios ${ }^{62}$ show women's inferior status. Botsford says it could be inferred from different descriptions of the women that during one and a half century since the earlier days of Solon women enjoyed free lives, but in the time of Pericles heir situation deteriorated, and in Medeia of Euripides the women began to revolt again. ${ }^{63}$

In my opinion, however, the different points of view of literary sources does not necessarily show chronological developments as Botsford suggested. Instead of it, the negative comments on women's activities could be supposed not to coincide exactly with the contemporary situation but are no more than expectations on a part of society, and women did not always behave according to such wishes. Especially in the second half of the $5^{\text {th }}$ century B.C. when the result of war, for which the men sacrificed themselves as soldiers, was almost brought to a deadlock, most women, seeking peace, resisted the initiatives of jingoism, such as described in Lysistrata. Their resistance, however, was not against all men, but militaristically-oriented men.

In the memorial address which was delivered for the dead fighting with the Lacedaimonians at the beginning of the Peloponnesian War, Pericles advised the widows not to be the object of gossip in the men's mouths, either for fort or for foible. ${ }^{64}$ Then, among the audience $s$ of the memorial address for the fallen in the war, there were women including the widows of the fallen. For example, according to Plutarch, Pericles, after his subjection of Samos, had returned to Athens, he gave honorable burial to those who had fallen in the war. And as he came down from the bema, while the rest of the women clasped his hand and fastened wreaths and fillets on his head, as though he were some victorious athlete, Elpinike drew near and said: "This is admirable in you, Pericles, and deserving of wreaths, in that you have lost us many brave citizens, not in a war with Phoenicians or Medes, like my brother Cimon, but in the subversion of an allied and kindred city." 65

The eulogy of Pericles for the restrained women is a kind of counterevidence for the notion that the women actually did not observe the so called virtue. ${ }^{66}$ And it should be underscored that women's virtue of reticence or temperance is just "advised" the examples of which are as follows:

61. Thukydides, II, xlv, 2.

62. I. Stobaios, Florilegium [Anthologion], ed. A. Meineke (Leipzig, 1856). However, in Stobaios not only comments disparaging women but opposite statements were presented, so that it could not be regarded as supporting one side (cf. A.W. Gomme, "Essays in Greek HIstory and Literature," 97).

63. G.W. Botsford, Hellenic History (N.Y., 1922),132, 219ff, 286ff., 332, 408f. cf. However, A.W. Gomme, "Essays in Greek History and Literature," 95-96 estimated Botsford's opinion as improper. This is why, if the Oresteia was performed in 457, Pericles' Memorial Address was in ca. 431, and Euripides' Medeia was in 431, the chronicle distance of Oresteia and memorial address was just 26 years, and Memorial Address and Medeia should be supposed having been presented in the same year.

64. Thukydides, II, xlv, 2.

65. Cf. Plutarchos, Perikles, XXVIII.3-4.

66. Cf. A.W. Gomme, "The Position of Women in Athens," 103. 
"Maidens in the age prior to 15years old [i.e. before assuming grave responsibility (polle epimeleia) as a matriarch of the house] have to be educated to see the least, to hear the least, and to question the least." Xenophon, Oikonomikos, VII.5.4.

"Women are advised to stay at home keeping grace (chreon esthlen)... " Euripides, F. 521

The existence of such advice suggests that the reality of the situation must have been contrary to the advice.

Then, it has been noticed that social requirements of the submissive virtue of the women became more salient in the age of Pericles' lifetime, the second half of the $5^{\text {th }}$ century, than before. Concurrently, it was the time when antipathy against war and the unrestrained wantonness of ekklesia rose to the surface. Lysistrata of Aristophanes was a paragon of the antiwar sentiment. The name of the female protagonist Lysistrata means "dissolving army", which is a symbol of the author's intention.

In Lysistrata, the men complained that the women whose support they contributed to rose in revolt against them.

"The women, whom at home we fed, like witless fools, with fostering bread, have impiously come to this - They've stolen the Acropolis, with bolts and bars our orders flout and shut us out. ." Lysistrata 260265.

The expression "the women whom at home we fed, like witless fools" in this text has been quoted as a proof of the degraded social position of women. Men's insults disparaging women do not at all guarantee the actual women's situation, even if they wanted to subjugate them under their own domination. To the contrary, Lysistrata retorts against the men, insisting that women are the main source of sovereignty to run a household. Furthermore, she denounces men who have provoked a war which has resulted in a deadlock, and their power-oriented propensity. And she boasts about her own ability to manage the city's economy instead of the men by exploiting the experience of household management, depriving the men of war funds so as not to push ahead with warfare any more. ${ }^{67}$

She defies the men who disparaged women who questioned the politics and war that the men had devoted themselves to. In Lysistrata (507-528), men and women quarrel with each other over priority. Women were not just confined inside the house weaving clothes, but assumed the responsibility for the household economy. On the other hand, men's authority was based on increased political initiatives as well as jingoism which had never existed previously. The Women tried to dissolve men's business, and expand the ethics of the household to the field of the state. If only women could

67. Aristophanes, Lysistrata. 486ff. 
succeed in a sexual strike to make men conclude warfare, all the women could be called Lysimachos (i.e. dissolving warfare). ${ }^{68}$

\section{War and Peace}

\section{Jingoistic Woman and Idyllic Man}

The motif of Lysistrata is the confrontation between men seeking after warfare and women pitted against them. Actually, however, it is not necessarily the case for all the men to be warlike, and all the women to be peace-oriented. For example, in the Clouds of Aristophanes, the roles of man and woman are reversed in comparison with that of Lysistrata. The mother wants her son to succeed politically, while the father advises him to come back to an idyllic rural life. ${ }^{69}$

The essential point here is that the concern of weaving women in the house could be politically oriented. Even if not acting on her own behalf, she could accomplish her ambition through her son. To the contrary, there are some among men who seek peace preferring rural rather than city life. It is shown in the episode of name-making dispute. The wife who was Megacles' nephew from an illustrious politically active family tried to add the word horse(hippos) to their son's name, but her husband Strepsiades opposed her as he preferred Philonides (phil+onos) which meant "loving rural pony" (onos). In the end, the two opinions were synthesized but the wife's opinion was proved stronger than the husband's, so that the name results in "Phidippides" with the meaning of "loving horse". From this episode it is shown that even women could be power-oriented no less than men, while there could be men who preferred a rural life and detested the political life of the city. The key point is that the confrontation is never between two genders, but between individual propensities.

\section{Increase of Social Inequality and the Contrast Between Rural and City Areas}

In the second half of the $5^{\text {th }}$ century B.C. the Delian League degenerated into the Athenian maritime empire and the gravity of politics and warfare in society increased. This resulted in the opportunity for the men to devise economic profits as well as social promotion. On the opposite side of society, however, there were two social groups which suffered relative disadvantage. One is the women of the households who degenerated to become relatively inferior to men who energetically assumed the affairs of political and military business; and the other is the agricultural farmer in rural, idyllic areas. The movement of the rural population into the city progressed gradually after the victory of the Persian War, and especially after the beginning of the Peloponnesian War. Aristeides who advised the

68. Aristophanes, Lysistrata. 553.

69. Aristophanes, Nephelai 39-77. 
Athenians to come down from their farms and live in the city after the Persian War, ${ }^{70}$ and later it is said that listening to Pericles' advice some of the Athenians, although most of them had been always used to live in the country, began to carry in their wives and children from the country, and all their household furniture, even to the woodwork of their houses which they took down. ${ }^{71}$

Thus, the increase of the city population was due to adjustment according to the establishment of the Athenian maritime empire. In Lysistrata, the women complain against the fact that a lot of funds had been for the war, which was provoked by the men after the Persian War. ${ }^{72}$ And they reprimand the men who made their children disappear in the war. ${ }^{73} \mathrm{On}$ the other hand, the women ended the war by use of the spiritual weapons of "persuasion"74 and "rationalism", ${ }^{75}$ recovering peace for the households as well as all Greece. ${ }^{76}$ The men come back from the war field, the thrifty life keeps going through wedding and the labor of idyllic rural life, ${ }^{77}$ and the love of a "household couple" (nymphikon) increased. ${ }^{78}$

In Ekklesiazusai Athenian men made a living mostly supported by money paid by the assembly (ekklesia) and the courts. ${ }^{79}$ Blepyros, the man who has been deprived by the women of the initiative of managing the citystate, hears from the chorus that it is not necessary to raise his family with the money earned by serving as a judge. ${ }^{80}$ And silver of private property and Persian gold are contrasted with the property of co-ownership which the women would secure. ${ }^{81}$ The Idea of extreme communism presented in Ekklesiazusai is a result of resistance to the side-effects due to militaristic campaign and the pursuit of hegemony.

Thus, the contrast between rural, idyllic, and communal life on the one hand, and urban, political and aggressive life on the other, was not static but advanced in an incessant conflict among the constituents of different propensities.

\section{Conclusion}

Opinions range from one extreme to the other on the position of women in Classical Athens. The orthodox view, coming down from the late 19thand early 20th-century, is that Greek citizen wives were generally despised

70. Aristoteles, Athenaion Politeia, XXIV.1.

71. Thucydides, II.14.

72. Aristophanes, Lysistrata, 648-655.

73. Aristophanes, Lysistrata, 579-590.

74. Aristophanes, Lysistrata, 203.

75. Aristophanes, Lysistrata, 432, 572, 1124, 1135.

76. Cf. H.P. Foley, "The 'Female Intruder' Reconsidered: Women in Aristophanes' Lysistrata and Ecclesiazusae," Classical Philology 77(1982), 9.

77. Aristophanes, Lysistrata, 595-607.

78. Aristophanes, Lysistrata, 378-84.

79. Aristophanes, Ekklesiazusai, 185-88, 206-8, 304-10; Ibid., Lysistrata, 624-25.

80. Aristophanes, Ekklesiazusai, 460-467.

81. Aristophanes, Eklesiazusai, 597-606. 
and kept in seclusion. From the first half of the 20th century, however, challenges have been raised against the alleged subjugation of women, with the contention that women were respected and enjoyed more freedom than was thought.

S.B. Pomeroy argued that the principal reason for the two viewpoints lies in the genre of the evidence consulted. Those, who rely predominantly, or exclusively, on the evidence from Classical tragedies, and believing that the heroines were modeled directly on the Athenian women of the fifth century B.C., determine that women were respected and not secluded. On the other hand, however, evidence from orators and other prose writers points to a low status. Thus, Pomeroy suggests not excluding either of the evidences. And she gives a warning that women should not be treated as an undifferentiated mass, and contends that different standards should be applied to the categories of citizens, resident foreigners (metoikoi), and slaves.

I agree with Pomeroy that women could not be treated as a social group. In my opinion, however, the difference of social group should not only refer to citizens, metoikoi, and slaves, as Pomeroy says, but to the citizens themselves. The criterion for citizenship is not one and the same for all the ages and places. Furthermore, in the same society there could be different criteria for citizenship. For example, one is the political right to assume military service and magistracies of the government, and to vote in the assembly, and the other is some traditional rights inside the family and its related kinship, demos and phyle, which were sub-structures of polis. The women, even if they did not take part in the government, were called citizens (aste or politis), as they had social and economic rights in the kinship society or other traditional sub-structures of polis. Actually, as considerable parts of the functions of polis were carried out on the level of its sub-structures, the politics of polis in ancient Greek society assume less significance than they do in the modern state today.

Actually women's social position shifts according to the social environments which are closely connected with the confrontation between militarism and pacifism as a theme presented in literature. The more hegemonic militarism is advanced, the more women's position in the home as well as the social and political gravity of other traditional sub-structures of polis goes down. Then, we cannot say that all the evidence to enforce women's submission and silence represent a reality, but, surely, at least some of it is just a hope of the men who are military-tropic. The relation between the sexes should be regarded not as static, but as a constant tension and competition. When the affairs the men pursue on the level of polis do not go well, the women immediately confront them.

\section{Bibliography}

Aischines, Loeb Classical Library.

Alexandridas, F. Edmonds ed.

Aristophanes, Acharneis. 
Aristophanes, Batrachoi.

Aristophanes, Thesmoporiazusai.

Aristophanes, Ekklesiazusai.

Aristophanes, Lysistrata.

Aristophanes, Nephelai.

Aristophanes, Troades.

Aristophanes, Hippolytos.

Aristoteles, Athenaion Politeia.

Aristoteles, Politika.

Botsford, G.W. Hellenic History. N.Y: The Macmillan Company, 1922.

Brock, R. "The labour of Women in Classical Athens." Classical Quarterly 442(1994): 336-346.

Carystios, FHG, IV, 358.

Davies, J.K. "Athenian Citizenship: The Descent Group and Alternatives." Classical Journal 73(1977): 105-121.

Demosthenes, Loeb Classical Library.

Dion Chrysostomos, D.A. Russell.

Ehrenberg, V. The people of Aristophanes: A Sociology of Old Attic Comedy. New York, 1962.

Euripides, Herakleidai.

Foley, H.P. "The 'Female Intruder' Reconsidered: Women in Aristophanes' Lysistrata and Ecclesiazusae." Classical Philology 77(1982): 1-21.

Foxhall, L. "Household, Gender and Property in Classical Athens." Classical Quarterly 39(1989): 22-44.

Garner, R. Law and Society in Classical Athens. N.Y.: St Martin's Press, 1987.

Gomme, A.W. "The Position of Women in Athens in the Fifth and Fourth Centuries B.C." In Essays in Greek History and Literature. Oxford: Basil Blackwell, 1937.

Hadas, M. "Observations on Athenian Women." CW 39(1936).

Haley, H.W. "The Social and Domestic Position of Women in Aristophanes." Harvard Studies in Classical Philology, vol. 1(1890).

Harrison, A.H.R. The Law of Athens, I Family and Property. Oxford: Clarendon Press, 1968.

Harrison, A.R.W. The Law of Athens: Procedure, v.2. Oxford: Clarendon Press, 1971.

Johnstone, S. "Women, property, and surveillance in classical Athens." Classical Antiquity 22-2(2003): 247-274.

Kitto, H. D. F. The Greeks. Harmondsworth, 1951.

Lacey, W. K.. The Family in Classical Greece. Ithaca, New York: Cornell University Press, 1968.

Patterson, C. "The case against Neaira and the Public Ideology of the Athenian family." In Athenian Identity and Civic Ideology, edited by A.L. Boegehold and A.C. Scafuro, 199-216. Baltimore: John Hopkins University Press, 1994.

Platon, Politeia.

Pomeroy, S.B. Goddesses, Whores, Wives and Slaves: Women in classical Antiquity. London: Pimlico, 1975.

Plutarchos, Moralia (Ethika).

Plutarchos, Solon.

Richter, D.C. "The Position of Women in Classical Athens." Classical Journal 67(1971): 1-8.

Sealey, R. A History of the Greek City States, ca. 700-338 B.C. Berkeley: University of California Press, 1976. 
Seltmann, Ch. "The Status of Women in Athens." Greece and Rome, 2nd ser., II, (1955):119-124.

Seltmann, Ch. Women in Antiquity. London, 1956.

Stobaios, I. Florilegium [Anthologium], recensuit C. Wachsmuth et O. Hense, Curt Wachsmuth, Otto Hense, Berolini: Weidmann 1884-1894.

Thucydides, Loeb Classical Library.

Wright, F.A. Feminism in Greek Literature: From Homer to Aristotle. N.Y.: Kennikat Press (1969). 
